\title{
Mardi Goena, Krida Beksa Wirama, and Harbiranda: Skilful Hand of KRT Jayadipura in Developing and Preserving the Javanese Culture, from 1920s to the 1930s
}

\author{
Indra Fibiona, ${ }^{1^{*}}$ Siska Nurazizah Lestari ${ }^{2}$ \\ ${ }^{1}$ Balai Pelestarian Nilai Budaya Daerah Istimewa Yogyakarta \\ ${ }^{2}$ Universitas Nusantara PGRI Kediri
}

*Corresponding Author:indra.fibiona@kemdikbud.go.id

\begin{abstract}
Ethical politics proclaimed by the colonial Government especially in education has made a room for the society in colonial Territories to preserve their culture. In addition, the idea of restoring the Javanese culture as a noble culture is mainly raised by the educated Dutch-

Received: Javanese nationalists at the beginning of XX century. The condition then

1 December 2017 triggered the elite royal (keraton) as well as artists to compete in the restorations and refinements. One of the elite royals and keraton

Accepted:

17 December 2017 Yogyakarta artists with his skilful hand, KRT Jayadipura tried to restore and refine Javanese traditional art in order to return the noble value of Javanese culture. His contribution in traditional art flows through Mardi Goena, Krida Beksa Wirama, and Harbiranda. KRT Jayadipura KRT works enjoyed by both local and international public. Therefore, the Javanese culture especially the noble art can be widely known and raises the public awareness of Java to continue to preserve it.
\end{abstract}

Keywords: Javanese Culture; KRT Jayadipura; Mardi Goena; Krida Beksa Wirama; Harbiranda.

\section{Introduction}

In 1920s, the existence of schools has become a common phenomenon that is widely found throughout the Netherlands East Indies territory. School establishment is one of the results from the Ethical Politics of colonial Government. Ethical politics in education also provided a space for the community within the colonial territory while maintaining their culture (Locher-Scholten 1981 in Legêne, et.al. 2015:161-163). John Pemberton revealed that the culture of colonial Netherlands gave a bad impact towards Javanese culture in 1800s until the 1920s (Adisasmito 2008). So, the idea to restore the Javanese culture as a noble in the early $X X$ century arised. One of the efforts was highlighting the appreciation of puppet (wayang) as a degrading traditional artwork to restore it (Legêne, et.al. 2015: 161-163).

The idea to restore the Javanese culture as a noble culture was mostly raised by the educated Javanese-Dutch nationalists at the beginning of XX century. In 1921, 
Sutapa, a master puppet wrote a letter to Java Instituute about the "setback" of wayang since there were many wayang shows presented "shallow" storyline, did not contain constructive educating values, such as the scene of endless battle over power and women and delivered uneducated and boring jokes. At the end of the letter, Sutapa asked Java Instituut to facilitate master puppet and artist training so that they have a more harmonious performance. Widespread complaints perceived by the traditional Javanese art critics was the lack of education with intellectual motives in the performances (Clara van Groenendael 1982 in Legêne, et.al, 2015:161-163).

In informal education, the discourse was related to Javanese culture restoration as a noble culture especially the appreciation of puppet. As the result, many puppetry schools were established. The first puppetry school with complete curriculum was opened in Surakarta by Susuhunan Paku Buwana X (1893-1939) in 1923. The school is Pasinaon Dhalang ing Surakarta, or more popular with Padasuka. A similar puppetry school or course, Habiranda, then opened in Yogyakarta in 1925. This course was under the wing of Sultan Hamengku Buwono VIII. The course also got support from Java instituut. The establishment of this course was also as the answer of Sutapa's letter as a master puppet in Java Instituute containing the "setback" of puppet since there were so many puppet shows presenting "shallow" storyline. The establishment of puppetry schools/courses indicated that the Keraton as a center of Javanese culture was trying to build itself as a "genuine" patron of the Javanese culture in the 1920s and 1930s, and "institutionalizing" the puppet as Javanese noble art (Legêne, et.al. 2015:161-163).

Beside highlighting the puppet, the idea to restore the Javanese culture as a noble culture also already made on traditional dance art earlier. In vorstenlanden territory, in the early twentieth century, prostitution veiled with arts (especially tayuban or taledhek) was opposed by the elite Java movement in order to uplift the status of Javanese arts. This was due to the status of taledhek dancer and tayuban offering the prostitution were incompatible with the idea of Javanese art as the product of noble culture (Sumarsam 1995: 121). In response to these conditions, Keraton Yogyakarta through the royal artists such as, Gusti Pangeran Haryo (GPH) Tejokusumo, son of Sultan Hamengku Buwono (HB) VII, KRT Wiroguno, KRT Jayadipura ${ }^{1}$ and other artists founded an art school.

Krida Beksa Wirama was established on August 17, 1918 with the organisation stucture of KRT Suryadiningrat as the Executive Director of KBW, Tejokusumo served as the Dance Director, KRT Wiroguno as Gamelan Director, and KRT Jayadipura as Poetry or Literature Director. In the body of KWB Organization itself, KRT Jayadipura was deemed to bring refinement, given KRT Jayadipura invented the copyrighted creations of dance and human puppet (wayang orang) costumes which brought a more lively performances (Sudarsono1984). Moreover, KRT Jayadipura also founded a dance studio with himself known as the artist who did the restoration and refinement on the art of dance and traditional music, despite his

${ }^{1}$ In some literature, KRT Jayadipura was written as Djajadipoera, Djajadipura, Djojodipoero, Djajadipuro, Jayadipura, or Joyodipuro, with the title Kanjeng Raden Tumenggung or Raden Mas. 
expertise in creating traditional music ensemble to accompany the traditional dance(Kussudiardjo 1992:29).

Prince Jayadipura is considered as a skillful artist capable of creating arrangement of Javanese gamelan music to be more beautiful, gentle and contain sensual mysticism. Although the arrangement was created based on the idea of Jayadipura, but literally it was arranged according to the elegant style of Keraton. Gamelan music wrapped in its melody was composed with full of surprises and dynamics. The composition was meant as an interlude in the dance performance (McPhee 2015). From the background described earlier, the main issue raised in this study is how the skilful hand of KRT Jayadipura in developing and preserving the Javanese culture in the 1930s? Based on the research problem, the analysis of the study should be formulated through a representative scope. As for the temporal scope in this research was the 1920s until 1939. In the 1920s was a period in which the endeavor and contribution of KRT Jayadipura rapidly improved especially regarding the Javanese cultural preservation (Djawa: Tijdschrift van het Java-instituut, Volume 19, No. 3, 1 September 1939). During those years, discourses to restore Javanese culture as a noble culture also arose. In 1939 was the final period as KRT Jayadipura passed away. Spatial scope in this research is Java region, particularly in Yogyakarta, given he did many activities in Yogyakarta.

The method of this research was carried out through several stages, which were topic selection, sources collection, verification (source criticism), interpretation, as well as writing (Kuntowijoyo 1995: 89). This research was also a study of sociocultural history by observing the character of R.M. Jayadipura from the perspective of social history and culture. The research focuses on the search the archive and literature studies to dig up information related directly or indirectly with the object of the research. Literature study was conducted by primary and secondary source searches to dig the related information about what was Jayadipura contribution, especially regarding the preservation of the Javanese culture. The data collection was carried out in some places, i.e. library of BPNB Yogyakarta: Yogyakarta Library; Yogyakarta Regional Library. In addition, the data collection was sources from some pages of digital library, such as Leiden Colonial Library, KITLV, Rijk Universiteit Groningen, and Het Nieuwe Instituut. Literature study was conducted to gain insight and to obtain resources related to the theme of research.

There are several studies discussing about the ideas of KRT Jayadipura, one of them is J. Kunts. The study discusses about the ideas of KRT Jayadipura on the development of traditional arts particularly music (Karawitan and Gamelan). J Kunts only focuses on the development of Javanese traditional music made by KRT Jayadipura and Linda Bandara. The research on KRT Jayadipura also carried out by Darto Harnoko et al. The study explains the life of Jayadipura and his ideas regarding the nationalism and the traditional arts, but the relationship between his attitudes and ideas about nationalism with the ideas of culture and the traditional arts were not investigated. 


\section{KRT Jayadipura Biography}

KRT Jayadipura was born in Yogyakarta in 1878, the second son of Raden Tumenggung (RT) Jayadipura (served as the Regent of Bantul) with his second wife Nyai Riya Segondo. Her parents named him Raden Mas (RM) Kobar when he was young (Harnoko, et al. 2014: 51). KRT Jayadipura father is the son of Ngabehi Resawilaya III, a royal servant (abdi dalem mantri pateyan) in Kraton Kesultanan Yogyakarta. Ngabehi Resawilaya III who is previously called as Ngabehi Samadegsana is the fourth son of Ngabehi Resawilaya I. The name of Resawilaya II was bore by the third brother Resawilaya III. KRT. Jayadipura is the grandson of BPH. Hadinegara, son of Sri Sultan Hamengku Buwono II. In addition, he also has two brothers, the oldest is RW. Kawindradipura and the youngst is R. Ay. Kumalawati. By this fact, KRT. Jayadipura is still the descendants of abdi dalem and one of the great-grandson of the rulers of Kasultanan Yogyakarta (Harnoko, et al., 2014:53-54). R.M. Jayadipura is the brother-in-law of Sultan Hamangku Buwono VIII (The Knickerbocker 1944: 20).

KRT Jayadipura became an abdi dalem of Kraton Yogyakarta who has a breadth of knowledge. He has another name, that is RM. Prawiranadi. The name is used when he serves as a abdi dalem of Kadipaten. Because of his discipline, intelligence, skills, abilities and integrity to serve the King, RM. Prawiranadi position rose to Wedana, so that his name became Raden Wedana (RW) Prawiranadi. His career catapulted to high scale, and then he became the Regent of Anom and was awarded the title Kanjeng Raden Tumenggung (KRT) Jayadipura. KRT Jayadipura also a member of abdi dalem kinasih so he was promoted to son-in-law of the Sultan (Harnoko, et.al. 2014: 53-54). Due to his kindness, in 1917 the land and Dalem Dipawinatan (now Dalem Jayadipuran) was donated to him by Raja Mataram Kasultanan. Originally, the dalem were the residence of Raden Tumenggung Dipowinata II who also replaced R.T. Dipowinata I with the status of hak anggaduh tanah (the right to use the land (considered owned by the sultanes of Yogyakarta). However, after the land and the building was returned to Kraton, Sri Sultan gave it to Jayadipura (Harnoko et.al. 2014: 53-54).

Since he was young, Jayadipura and his brothers served as abdi dalem as well as actively engaged in the development and preservation of Javanese art, particularly in Yogyakarta (Harnoko, et.al. 2014). KRT. Jayadipura started dabbling in art since teenage. Thanks to his talent, intelligence, skill and perseverance he was famous as a multifaceted artist. As a skilled artist, he was not only master one field of art but also other arts. He is an expert and master of traditional dance, karawitan, sculpture, leather craft, statue, painting, and masks as well as building designer (architect) (Harnoko 2014:53-55). Because of his perseverance, talent, and the support of his parents, he was able to master all of his art skills. Only few of them were directly learned from people. When he learned the ins and outs of dance, KRT Jayadipura nyantrik $^{2}$ to R. Riya Kartaatmaja, a dance teacher in the kraton Kasultanan Yogyakarta who has produced quite a number of skillful dance artists or figures

${ }^{2}$ Nyantrik = learn intensively 
(Harnoko, et.al. 2014: 53-54). It is indeed undeniable that his art sense was taken from his grandfather i.e. BPH. Hadinegara, the son of Sri Sultan Hamengku Buwono II who was dabbling in the field of literature (Harnoko, et.al. 2014: 53-55).

Javanese culture internalized within KRT Jayadipura was the result of his father's contribution as an abdi dalem. Tumenggung Jayadipura (father of KRT Jayadipura) is known as a costume designer for human puppet (wayang orang). The costumes were designed in accordance with the characters reflected in the shadow puppet. At that time, Tumenggung Jayadipura served as the head of a division in charge of designing costumes for human puppet. The divison was Kawedanan Hageng Gladag lan Kriyo (Kutoyo 1997: 151). Costume with all its rules (ageman) was actually set by the Sultan HB VIII. KRT Jayadipura was only assigned to design according to the rules issued by Sultan HB VIII. As a fashion designer, KRT Jayadipura drew the concept on a piece of paper then reviewed or approved by the Sultan HB VIII himself (Dewan Kesenian Propinsi DIY 1981: 181). Inheriting artistic talent from his father, KRT Jayadipura then became an all-rounder artist who is trusted by Keraton as an architect, dance choreographer and gamelan music arranger.

\section{Preserving Javanese Culture}

KRT Jayadipura were devoting himself to preserve the traditional Javanese arts since he was young. His endeavor began in 1908, when he founded an agency organizing the traditional Javanese arts courses, together with Raden Mas Prawiradipoera, Prawiraatmadja and Mr. Lie Djeng Kieem from Hermani studio. Its members continue to grow, but the studio was still managed independently. Javanese art and cultural regeneration generally has not been made that much at that time. KRT Jayadipura and friends felt concerned about the internalization of Javanese culture, such as music, Javanese traditional dance, and puppetry. He and his friends had the idea to create an intellectual and learning center for traditional Javanese arts so that the cultural preservation could run in an ongoing basis.

\section{Participation in Dance and Music (Mardi Geona Studio)}

In 1919 he established Mardi Goena Studio. During its development, Mardigoena Studio opened classes for studying traditional music and dance in 1926 (Djawa: Tijdschrift van het Java-Instituut, 1 September 1939). As time goes by, KRT Jayadipura also made Mardi Goena as a studio presenting traditional Javanese music and dance for tourists who visit Kraton Yogyakarta. Dance performances were presented approximately in two hours with various manifestations of gallant and decent (gaharu) Javanese dance, so it gives the impression that Javanese dance has a high aesthetic value. One of the classical dances performed by boys and girls in the show was KRT Jayadipura creations. KRT Jayadipura also created attractive mask dance in front of the tourists and reaped praises. The impressiveness of the dance created by KRT Jayadipura has made the artwork as a part of cultural inventory of the kraton. Therefore, the performances held outside the kraton must get permission from the 
sultan to support the existence of the studio run by KRT Jayadipura. The classical dance show performed outside the Keraton was allowed by the Sultan, with the consideration that Javanese music and dance could be widely known in the future (especially by the tourists visiting Yogyakarta), so the appreciation from the community towards traditional art could increase (Djawa: Tijdschrift van het JavaInstituut, 1 September 1939).

Mardigoena dance performances under KRT Jayadipura were once held when groups of tourists visiting Yogyakarta on 20 March 1930. The arrival of the tourists was the right momentum for KRT Jayadipura to introduce Javanese culture to European people. After a visit to Borobudur, dozens of tourists who came from Franconia (Germany) was welcomed by the management and staff of the Grand Hotel YogyakartaYogyakarta. They were presented to human puppet performances in the evening. The first impressions perceived by the tourists towards Javanese traditional dance that it was a strange performance, but after enjoying it until the end of the show they felt that it was very impressive (De Indische Courant, March 24 1930).

KRT Jayadipura also collaborated with Nitour and Grandhotel in order to facilitate the tourists to enjoy the traditional art directly at Mardi Goena Studio. It is aimed so that the Javanese culture could be widely known. In addition, the show was also presented in his residence as Mardigoena Studio Manager. Art performance presented at the residence of KRT Jayadipura was to improve the performance of Mardigoena Studio, especially in the development of community traditional arts in the appropriate environment. The show was held in a big hall (pendapa) at the residence of Jayadipura pendapa which is considered as representative because it has a large audience capacity. On the other hand, the show was not only enjoyed by the foreign tourists, but also by the locals who want to enjoy noble art performance from their own tribe (Djawa: Tijdschrift van het Java-Instituut, 1 September 1939).

As the head of the studio engaged in the preservation of Javanese culture, especially in music, theatre (human pupet), dance and puppetry, KRT Jayadipura managed to raise the value of Javanese culture. Thanks to him, Javanese music, dance, and human puppet obtain a good appreciation from European people. Performance prepared by KRT Jayadipura was an impressive performances, which was able to amaze the audience. Furthermore, KRT Jayadipura also managed to present performances of traditional music, dance and human puppet with a moderate cost. Human puppet performances were foreign to the European people, given that they came from countries with different culture. Sometimes there was various opinion and comment both good and bad even scorn threw by the tourists (the audience). KRT Jayadipura received it as a challenge so that human puppet show could amaze and enthrall the tourists. The show also had a positive propaganda value with the intention to deliver an attractive show which can be appreciated and enjoyed by the local and global community (De Indische Courant, 24 March 1930). 


\section{The Institutions of Music and Dance Art (Krida Beksa Wirama)}

Contributions from KRT Jayadipura KRT in other art branches were shown through Krida Beksa Wirama, an institution of Javanese traditional music and dance art course. During its development, Krida Bheksa Wirama opened some branches in Jakarta and in Malang, East Java. The institution teaching the traditional art was utilized by the Sultan Hamengkubuwono VIII to spread the Kraton Yogyakarta art which later fused with the nationalism of Indonesia. Almost all dance teachers in Kraton Yogyakarta were involved in the management of Kridha Beksa Wirama and had a key position. Beside KRT Jayadipura, the key figures in Krida Beksa Wirama were Prince Suryodiningrat, Prince Tedjokusumo, KRT Wiroguno and other Princes. Prince Tedjo Koesoemo as the Commissioner, while R.E. Atmosoeprato served as a representative on the board of dance association of Krida Beksa Wirama. The establishment of Krida Beksa Wirama also came with the ratification of the articles of association. Several dances which included in the teaching curriculum at krida Beksa Wirama were dances telling the battle between the Wara Shikhandi and Resi Bisma which is a part of Baratayuda story (epic of full-scale war of Mahabharata). At that time, Golek dance was one of the popular dances, performed by using wooden masks or puppets, as well as other popular dances. One of these artworks was choreographed by KRT Jayadipura (Djawa: Tijdschrift van het Java-Instituut, 1 September 1939). It was not very long until this institutions recruited many members. In few months, dozens of people joined as the members to learn Javanese culture. The members were greatly increased due to the close relationship of the Figure 1 in Krida Beksa Wirama with the community (De Sumatra Post, 10 August 1925).

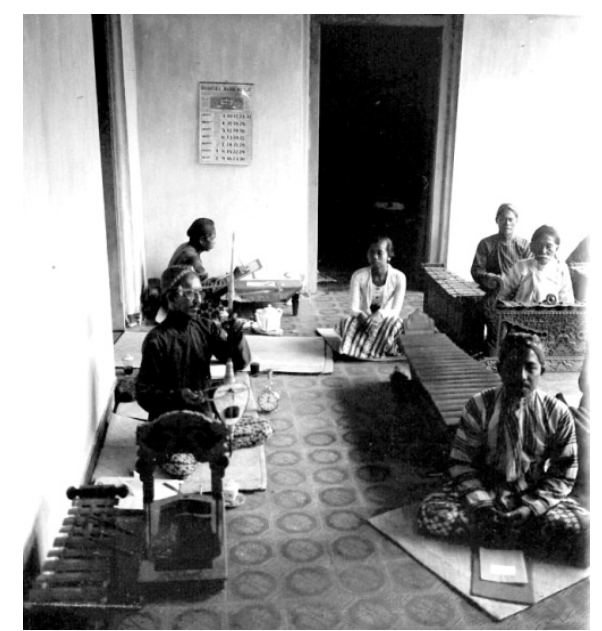

KRT Djajadipoera (using Rebab) while practicing music at his home (now the building in the western side of BPNB DIY).

Source: Collection of Nationaal Museum van Wereldculturen in

http://collectie.wereldculturen.nl

\section{School of Puppetry (Habiranda)}

Because of his contributions to Javanese traditional art, KRT Jayadipura is regarded as a great figure in preserving Javanese arts. One of his contributions in art is shown 
by the establishment of puppetry courses, together with Keraton and Java Instituut. The course was intended to train the master puppet so that they capable to present the storyline of the puppet and the puppet performance attractively (Cooper 2000). RM Gondoatmodjo was appointed to be the head of this puppetry institution. The treasurer was R. Roedjito and the secretary was served by RM Jayadipura. The idea of Jayadipura in establishing the school of puppetry was also an attempt to preserve the traditional art of puppet as the manifestation his idea in the real work, given that he was active in Java Instituute (Djawa: Tijdschrift van het Java-Instituut, 1 September 1939).

His initiative in founding the school of puppetry was realized on Sunday Wage date of 5 Mukarom year of Be 1856 or 1925 in YogyakartaYogyakarta. The name of the school of puppetry was "Habiranda" which is shorter term for daridari $\mathrm{Ha}$ murwani, Bi-wara, Ran-cangan, Da-lang. This school was also funded by Sri Sultan Hamengkubuwono VIII. As for the executor, BPH Suryadiningrat and KRT Jayadipura were appointed. KRT Riya Gandaatrnaja was the chairman of Harbiranda. Moreover, KRT Jayadipura served as the secretary, while BPH Suryadiningrat served as the general assistant. This course also has tutors. KRT Jayadipura as the director and tutor teaching the common knowledge (Kawruh) in puppetry. The division of other tutors was history taught by R.W. Prawiradipura, Sulukan division taught by R.T. Madubranta, Pakeliran taught by R.B. Cermawicara. R.M. Djajadipura also has a great contribution in preserving the knowledge of the puppetry, especially through Harbiranda. He collected paugeran or waton (regulations or formal instructions) in puppetry, such as janturan and rote-memorisation within it (Kutoyo 1997: 231).

\section{Javanese Culture Devoutness and Preservation}

Other contribution of KRT Jayadipura were his innovation and creation in puppetry in designing the performance flow of special wayang Poerwa and shorten it into a three-hour attractive performance in 1930 (The Magazine of the Low Countries,1944: 20). KRT Jayadipura came up with the innovation in human puppet show but based on the standard. Usually, pëtilan (the story of the play) lasted for 12 hours or shortened to 3 to 6 hours to make it more attractive (Djawa: Tijdschrift van het Java-Instituut, 1 September 1939). Achievements of KRT. Jayadipura were also inscribed in fine art, that is statue and sculpture from stone for house building, one of them was in the form of umpak. Umpak created by KRT. Jayadipurawas wa so popular among the Governors because it has a smooth and aesthetics figure. KRT Jayadipura was also contributing in the development of the art of mask. His artworks of masks can be found in Kraton Yogyakarta that are ape masks used in Langen MandraWanara, Rahwana masks, and animal masks used in Ramayana story. He also made PentulTembem masks and Regol-Gunungsari masks. Face of Regol mask was made to fit with his own face, while Gunungsari mask was made fitting for KRT. Brongtodiningrat face. KRT. Jayadipura learned about sculpture and statue from Walter Spies. But 
rather, Walter Spies also learned Javanese Arts from KRT. Jayadipura in return, so they exchanged knowledge. Furthermore, in the process of sculting, he got a lot of influence from Walter Spies (Harnoko et. al. 2014: 53-54).

KRT Jayadipura is a multitalented figure with a diverse works particularly in architecture. Works of KRT Jayadipura can be found in almost all new buildings in Keraton Yogyakarta under Sri Paduka Sultan Hamengkubuwono VIII rule. KRT JayadiPura is an architect leader whose work is highly appreciated by Sri Paduka Sultan Hamengkubuwono VIII. In creating Javanese architecture design, KRT Jayadipura received a lot of help from Raden PanewoeKartawiraga to draw sketches (De Loos, 1967). Some architectural works produced by KRT Jayadipura in Kraton Yogyakarta environment are Bangsal Manis, on the south of Bangsal Kencana, Mandalasana, Regol Kasatritan, Regol Dana Pertopo, Regol Wuni (now Regol Kanikkataya on the south of Bangsal Manis). Architectural works of KRT Jayadipura is greatly influenced by his observations on the surroundings (Harnoko et.al. 2014: 53-56).

His remarkable skill in art is proved by his fascinating works. KRT Jayadipura's mastery of art has been widely known since the 1920s until 1930s (De Loos, 1967). Some of his artworks are in the form of masks, architectures, traditional dance choreography, and gendhing arrangements (gamelan music). In addition, his expertise in crafting is also shown through a set of gunungan along with its equipments used in traditional ceremonies. KRT Jayadipura was also actively participating in traditional ceremonial held by keraton Ngayogyakarta Hadiningrat. Assisted by his students, he always prepares gunungan to carry out Garebeg ceremony (Het nieuws van den dag voor Nederlandsch-Indië, 11 August 1935).

KRT Jayadipura also has an outstanding musical skill, shown by his expertise in producing gendhing arrangements, as well as writing Javanese musical notes to be easy to read. KRT Jayadipura, JS Brandts Buys, RM Soerjapoetra, Jaap. Kunst revealed that there is still a lot to be anticipated from the future of Javanese traditional music (Karawitan). It is proved by the many audiences who are interested in Javanese music after they wrote a scientific essay with the theme "de ontwikkelings mogelijkheden van de muziek op Java" ("possibility of music development in Java") presented at Javanese cultural congress, in Bandung in 1921 (Hadiwidjana 1922).

KRT Jayadipura's ideas in art were transferred into a book entitled Gegevens met betrekking tot den Gamelan or Information about Gamelan music in 1921. His writing about the ideas of arranging songs at the congress of Javanese culture held in Bandung (Kunst 2013: 461). KRT Jayadipura also invented a gamelan musical notation system collaborated with Linda Bandara (who is also a student of Jayadipura in Krida Beksa Wirama), Figure 2 describes their relation. They produced a way of notation writing in layered lines. Pelog tone is written on the line, and slendro tone is written between the lines. The system was inspired by European musical notation writing system (similar to common musical notes writing). The notation writing system created by KRT Jayadipura and Linda Airport is suitable for the Gamelan orchestra performance. Walter Spies stated that there are so many 
repertoires of melodious notes of kraton Yogyakarta songs, yet there has not been much modification made to rewrite the notation into sections, according to the instrument. If the notation can be written in a more readable and simplified method, it will be very helpful for scoring (music) in the Gamelan orchestra. His ideas for the development of Javanese traditional music were also followed by some niyagas in YogyakartaYogyakarta. Only a few niyaga were familiar with Gendhing Keraton and traditional Gendhing and one of them is KRT Jayadipura. Moreover, KRT Jayadipura is the one who has initiative to write the gendhing notation and combine the parts of the gending so that it becomes intact (Kunst 2013: 354)
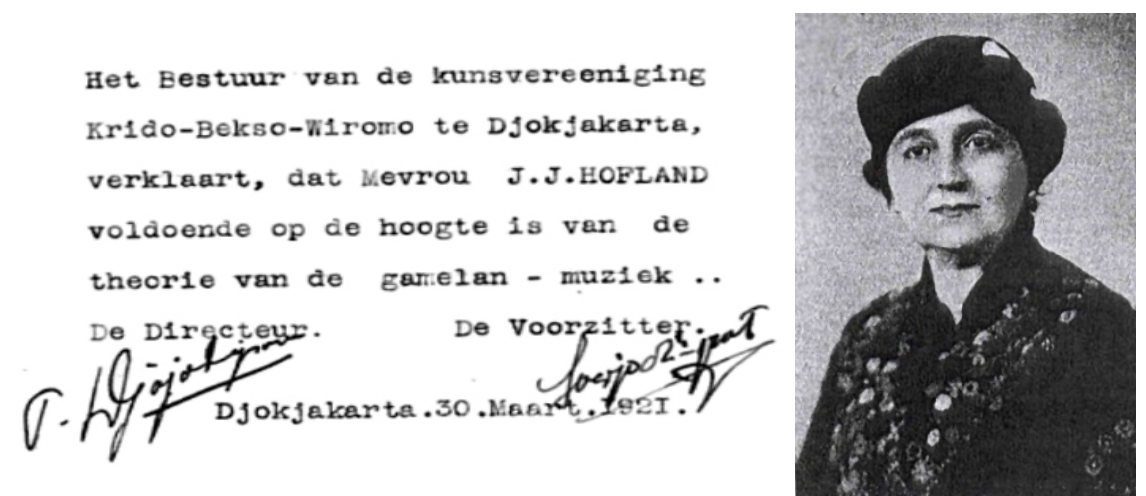

Figure 2. Left: Statement letter of Board of art association Krido Beksowiromo Yogyakarta stating that Mrs. JJ Hofland has the knowledge of the theory of gamelan music, signed by

KRT Jayadipura (director) and R. Soerjadiningrat (chairman).

Right: Portrait of J.F. Hofland aka Linda Bandara

Source: Van Dijk, 2007 and nederlandsecomponistes.zierikzeenet.nl, 2016.

KRTJayadipura contribution in the development of other Javanese music is marked by the bookcontaining information about Javanese musical notation. The book is titled piwulang nabuh gamelanpublished by Komisi Pasinaon Penabuh Gamelan Radyapustaka Surakarta (Sumarsam 1995: 133-135). His passion for Javanese music was manifested by contributing to Javanese music congress event in Bandung on December 20, 1921. KRT Jayadipura with his students and colleagues, JJ Hofland and Mr Brandts Buys sent some recommendations for the sake of the congress (Bataviaasch Nieuwsblad, 20 December 1920). The cultural congress held in December 1921 in Bandung was the first congress of Javanese music under the auspices of the Java Institute. One of the agenda of the congress is the development of Javanese music, so the preservation of Javanese music remains continue. Some musicologists gave their views on this matter. Through theirconveyed ideas, KRT Jayadipura considered that European peoplewas less interested, even degrading the Javanese traditional music. Linda Bandara explained that the moment was an important moment to record the traditional Gamelan melodies to preserve it. This is in line with the thoughts of KRT Jayadipura (Dijk 2007).

The use of notation system began to bloom after java Instituut with its members of the intellectuals of Javanese and Dutch held a Javanesetraditional musical script writing competition. The notation system used by the Javanese and 
Dutch intellectual musicians was easy for the Niaga in understanding Javanese gending, so some gending with difficult notation can be played well. This attracted a Dutch musicologist, Brandts Buyss (1924) to hold a Javanese traditional music notation method contest with the criteria of simple implementation. The announcement of the contest was published in Djawa magazine. KRT Jayadipura was also asked by J. Kunst, a Dutch musicologist to organize a complete Gamelan performances and make recording (using gramaphone) in Jogja, precisely at residence of KRT. Jayadipura in May 1931 (Soerabaijasch Handelsblad: 1931). This record is for the memory of art as part of Javanese noble culture can be maintained.

During the last years of his life, KRT Jayadipura wrote another music script. The manuscript was written specifically for his students who studied Gamelan, who were joined "Mardi Goena" studio. The script used a notation type of do-re-mi-fa-sol which was selected and changed as $j a, d a, p e, g e n g, n e$, and $b a$ that have been derived from the names of the tones. The use of the notes is to match with the beat (interpunctual beat), as in the Gamelan notation of kraton Yogyakarta. The gong instrument notation is indicated by the word gong in the Javanese script, beat just on the beat of the gong. Counterpart (pasangan) ta indicates the gong beat, pasangan na indicates kenong beat; pasangan pa: to indicate a kempul beat, and pasangan wa to for Wela beat. The notation writing method developed by KRT Jayadipura is actually a form of simplification with minimal modification from P. Adiwinata notation method. The main reason why KRT Jayadipura made the notation method is for the gamelan musician to remember the names of the tones, so that the accuracy (interpunctual) of the tones in the Gamelan music creates a harmonious melody (Kunst 2013: 355). In addition, many Niyaga were oriented in his ideas about traditional art, especially in the notation writing used in gamelan music. Jayadipura developed an easy and understandable gamelan music notation writing system to learn, so that the preservation of Javanese traditional art can be maintained continuously (The Magazine of the Low Countries, 1944 : 20).

KRT Jayadipura is known as Ir. Sukarno's friend who is multitalented in art. This is evidenced by his skill in creating dance and music performances for traditional art tourism at Grand Hotel Yogyakarta. RM Jayadipura also worked with several musicians or gamelan music instrument makers in Ngabean to make kenong and kempul instruments with unique sound then multiplied it to produce a more spectacular niyogo orchestra. In the following years, this idea was later adapted by several music experts; one of them is Yogyakarta music experts, Lee Jeng Kim, in creating a more festive orchestra. The idea of KRT Jayadipura in the instrument compositions improvisation then became more popular, and widely aired through gamelan music broadcasts on Radio Republik Indonesia after 1945 (Tashadi, et. al. 1993: 93). This achievement indicates KRT Jayadipura has a grand passion for Javanese traditional art. KRT Jayadipura vision and mission in the development of Javanese culture is to be widely known by the people as well as being a national culture alongside with other tribe cultures. 


\section{Conclusion}

The idea of restoring Javanese culture as a noble value culture in the twentieth century has become a competition for Javanese cultural observers, including allround artists from keraton Yogyakarta, KRT Jayadipura. As an abdi dalem of Kraton Yogyakarta whose broad knowledge, discipline, intelligence, skill, and sincerity to serve his king, his heart was moved to contribute in preserving Javanese culture in the keraton Yogyakarta.

It is realized in various types of arts including music, dance and performing arts. The arts were facilitated in various institutions, such as mardiguna, krida beksa wirama, and habiranda. Those institutions are under auspices of keraton Yogyakarta. In addition, the skilful hand of KRT Jayadipura succeeded in creating a gamelan notation writing system in collaboration with Linda Bandara. The works of KRT Jayadipura were not only enjoyed by the local people around the keraton but also by foreign tourists. This is intended to introduce Javanese culture, especially the noble arts to be widely known.

\section{References}

Adisasmito,N. D. (2008). “Karakter Visual dan Gaya Ilustrasi Naskah Lama di Jawa Periode 1800-1920" in Jurnal Visual Art E Design ITB, Vol. 2, No. 1, 2008, 54-71. Bagong Kussudiardjo. (1992). Jejak dan pengakuan Bagong Kussudiardja. Yogyakarta: Padepokan Press.

Cooper, N. I. (2000). Singing and Silences: Transformations of Power through Javanese Seduction Scenarios. Jurnal American Ethnologist 27 (3)August.

De Loos, J. T. (1967). “De Gouden Koets van de Sultan. Bijdragen tot de Taal-, Land- en Volkenkunde 123 (3): 366-372.

Dewan Kesenian Propinsi DIY. (1981). Mengenal Tari Klasik Gaya Yogyakarta. Dewan Kesenian Prop- DIY, Proyek Pengembangan Kesenian DIY, Department Pendidikan dan Kebudayaan.

Dijk, H. (2007). De Oostenwind Waait naar het Westen: Indische Componisten, Indische Composities, 1898-1945. Leiden: KITLV Press.

Easthorpe, A. (2004). Englishness and National Culture. London: Routledge.

Hadiwidjana. (1922). “De Javaansche Zang Onder De Regelen Van De Westersche Muziek-Techniek." Djawa: Tijdschrift van het Java-instituut 2 (2).

Harnoko D., et.al. (2014). Rumah Kebangsaan : Dalem Jayadipuran Periode 1900 - 2014. Yogyakarta: BPNB Yogyakarta.

http://collectie.wereldculturen.nl, accesed at $28^{\text {th }}$ September 2017, 8.00 PM.

Kunst, J. (2013). Music in Java: Its History, Its Theory and Its Technique (Reprinted). London: Springer.

Kuntowijoyo. (1995). Pengantar Ilmu Sejarah. Yogyakarta : Yayasan Bentang Budaya. Kutoyo S.(1997). Sejarah Daerah Daerah Istimewa Yogyakarta. Jakarta: Direktorat Jenderal Kebudayaan.

Legêne, S., and Bambang Purwanto, Henk S. Nordholt (2015). Sites, Bodies and Stories: Imagining Indonesian History. Singapura: NUS Press. 
Mc Phee, C. (2015). A House In Bali. N/A: Pickle Partners Publishing.

Moeljono. (1989). R.W.Y. Larassumbogo: Karya dan Pengabdiannya. Jakarta: Departemen Pendidikan dan Kebudayaan, Direktorat Sejarah dan Nilai Tradisional.

Sudarsono. (1984). Wayang wong: the state ritual dance drama in the Court of Yogyakarta. Yogyakarta: Gadjah Mada University Press.

Sumarsam. (1995). Gamelan: Cultural Interaction and Musical Development in Central Java. Chicago: University of Chicago Press.

Surtihadi, R. M. (2014). "Instrumen Musik Barat dan Gamelan Jawa dalam Iringan Tari Keraton Yogyakarta." Journal of Urban Society's Arts 1 (1) April.

Tashadi, et.al. (1993). Refleksi Nilai-Nilai Budaya Jawa: Suatu Kajian Terhadap Serat Sakeber. Yogyakarta: Direktorat Jenderal Kebudayaan

The Knickerbocker: The Magazine of the Low Countries (1944) Atlantic observer.

“De Dalang Cursus." De Sumatra post, 10 August 1925.

"Het verleden der Javaansche Muziek Javaansche Muziekz." Bataviaasch Nieuwsblad 20 December 1920.

"Musicol Studies." Soerabaijasch Handelsblad, 8 May 1931.

"Terug naar het Gebergte." Het nieuws van den dag voor Nederlandsch-Indië, 11 August 1935.

“Uit Djokja: Toeristen bezoek.” De Indische courant 24 March 1930. 